\title{
Selection of promissory crops of wild cherry-type tomatoes using physicochemical parameters and antioxidant contents
}

\author{
Lina María Londoño-Giraldo ${ }^{1^{*}}$ (D), Jessika Gonzalez² (iD), Andres Mauricio Baena ${ }^{3}$ (D), \\ Omar Tapasco 4 (D), Eduardo Javid Corpas² (D), Gonzalo Taborda³ (iD \\ 1. Universidad Libre - Facultad de Ciencias de la Salud Pereira - Risaralda, Colombia. \\ 2. Universidad Católica de Manizales - Programa de Bacteriología - Manizales, Caldas, Colombia. \\ 3. Universidad de Caldas - Departmento de Química - Manizales - Caldas, Colombia. \\ 4. Universidad de Caldas - Departamento de Matemáticas - Manizales - Caldas, Colombia.
}

\begin{abstract}
Tomato is considered a fruit with a high food demand across the world due to its high antioxidant capacity. Lycopene content in tomato has been widely studied, particularly in cherry-type tomatoes which are considered a high source of lycopene for humans. The aim of this study was to analyze the differences in terms of concentration and variation of diverse physicochemical parameters of quality (acidity, vitamin $\mathrm{C}, \mathrm{pH}$, ${ }^{\circ}$ Brix, color coordinates $L^{\star}, a^{*}$ and $b^{\star}$ ) and, antioxidants like $\beta$-carotene and lycopene in 11 accessions of cherry-type tomatoes, considering the advantages of antioxidants for human health. Multicriteria analysis and other tests showed substantial differences among the accessions. IAC401 was associated with the best physicochemical characteristics of a promissory cherry-type tomato for cultivation due to its association with functional food, followed by IAC426R and IAC1624. This study allowed an innovative association of physicochemical characteristics and antioxidant contents of cherry-type tomatoes through multicriteria analyses which enable the analysis, elimination, and proposal of promising accessions for their use in future crops which will promote the best intrinsic features of tomato to be used in the studied region. In this case accessions with the highest scores offer not only optimum amounts of antioxidants and highest levels of organic acids and sugars.
\end{abstract} Key words: Iycopene, $\beta$-carotene, vitamin C, soluble solids, Solanum lycopersicum var. cerasiforme.
Received:

Jul. 16, 2019

Accepted:

Feb. 3, 2020

Section Editor:

Ricardo Giehl

${ }^{\star}$ Corresponding author: lina.2271528593@ucaldas.edu.co

\section{INTRODUCTION}

Cherry-type tomato (Solanum lycopersicum) represents one of the most prized fruits across the world due to its properties and physicochemical attributes, especially because of its high antioxidant content and vitamin C (Tian et al. 2016). Main carotenoids synthesized from tomato are phytoene, phytofluene, lutein, $\beta$-carotene, and lycopene (Coyago-Cruz et al. 2018), which are tetraterpenes. Lycopene and $\beta$-carotene act as natural lipophilic antioxidants, which are widely known for their activity in cancer prevention, heart disease and immunological system protection (Tian et al. 2016).

In tomato, lycopene concentrations oscillate between 8 to $40 \mathrm{mg}$ of lycopene/kg (Giudice et al. 2017). It is the primary cause of the red pigment in tomato (Ayala-Zavala et al. 2008). Besides, lycopene is a strong sequester of 
singlet oxygen twice times more powerful than $\beta$-carotene (Teixeira et al. 2009). $\beta$-carotene is the most powerful precursor of vitamin A (Lucini et al. 2012). These antioxidants are associated with intrinsic properties and physicochemical parameters (i.e. acidity, $\mathrm{pH}$, soluble solids) of tomato. They also have strengthened the concept of the quality of tomato beyond its external features (weight, shape, color, size) (Coyago-Cruz et al. 2018). This set of characteristics must be considered when consumers need a fruit with optimal nutraceutical, appetizing and functional properties. Tomato intake helps to prevent cardiovascular diseases and cancer because of the benefits provided by the lycopene to human health (Thies et al. 2016). One of the most special mechanisms in the cancer-cell description is the "Warburg effect" (Corbet et al. 2016), which makes cancer cells extracellular microenvironment acid by the conversion of pyruvate in lactic acid which activates the glycolysis even in the presence of oxygen. Cancer cells adapt to $\mathrm{pH}$ and proliferate; however, normal cells suffer from failed programming which may trigger mutations due to the acidic condition. Also, they inhibit the function of natural killers and T cells, which oversee tumor suppression (Rabiee et al. 2018).

Cherry-type tomato is valuable because it contains interesting lycopene concentrations than other tomato cultivars, such as the chonto-type tomato (Aguirre and Cabrera 2012). Cherry wild tomato genotypes keep this trait and have a higher content of sugars at a maximum ripening stage (Aldrich et al. 2010), a condition which makes cherry-type tomato sweeter and thus appetizing, intensifying flavor and aroma of this fruit. This situation has triggered information related to extraction, separation and quantification methods in this matrix.

Choosing carotenoids extraction techniques is the most critical criterion for effective extraction and mainly depends on the carotenoid composition. Acetone/hexane extraction is generally used for polar and nonpolar antioxidants (Poojary and Passamonti 2015; Giudice et al. 2017). However, there are some other types of clean extraction methods, different from the conventional methods, which offer an advantage because they do not use toxic solvents (Zanfini et al. 2017; CoyagoCruz et al. 2017; Schweiggert et al. 2017; Melfi et al. 2018; Coyago-Cruz et al. 2018).

To contribute to the strengthening of the productive local chains, this study aimed to analyze the variation of physicochemical parameters of quality and the differences in concentration of antioxidants, $\beta$-carotene and lycopene, in 11 accessions of wild cherry-type tomatoes. This work proposes promissory material for commercialization using decisional multicriteria analysis based on nutritional requirements to be also considered as a functional food.

\section{MATERIAL AND METHODS}

\section{Plant material}

Wild cherry-type tomatoes analyzed belong to Agronomic Institute of Campinas, Brazil (IAC1621, IAC1624, IAC391, IAC401, IAC412, IAC426 and, its variant named IAC426R), and accessions from the Tomato Genetics Resources Center (TGRC) of the University of California, Davis (LA1480, LA1705, LA2076, and LA2692). The fruits were collected from intermediate infructescence of crops cultivated under hydroponic conditions. The selected accessions were considered as promissory according to morphoagronomic parameters proposed by Agudelo et al. (2011). The analyzed tomato accessions, color, shape, fruit weight and origin are shown in Table 1.

\section{Samples preparation}

Tomato fruits were selected at full ripening stage. For red common tomato, fruit was selected at five stage with more than $90 \%$ of its surface showing the red color according to NTC 1103-1. Yellow and pink tomatoes were collected with a stable and uniform color at ripening. One hundred grams of fruit were homogenized for $60 \mathrm{~s}$ at $25^{\circ} \mathrm{C}$ according to Servili et al. (1998). Tests were performed with fresh homogenized juice without the addition of any other components. Samples were analyzed by triplicate. 
Table 1. Analyzed accessions of wild cherry-type tomatoes.

\begin{tabular}{ccccc}
\hline Code & Country of origin & Fruit Color & Fruit Shape & Average fruit Weight (g) \\
\hline LA1480 & Ecuador & Red & Round & 19.9 \\
\hline IAC1621 & Brazil & Red & Round & 20.1 \\
\hline IAC1624 & Brazil & Red & Round & 24.1 \\
\hline LA1705 & Mexico & Yellow & Round & 16.2 \\
\hline LA2076 & Bolivia & Red & Round & 12.7 \\
\hline LA2692 & Peru & Red & Round & 16.29 \\
\hline IAC391 & Brazil & Red & Round & 26.4 \\
\hline IAC401 & Brazil & Red & Round & 11.4 \\
\hline IAC412 & Brazil & Pink & Oval & 21.6 \\
\hline IAC426 & Brazil & Red & Round & 16.4 \\
\hline IAC426R & Brazil & Red & 18.5
\end{tabular}

IAC: Accessions from the Agronomic Institute of Campinas, Brazil; LA: Accessions from the Tomato Genetics Resources Center (TGRC) of the University of California, Davis.

\section{Assessment of the physicochemical parameters}

Titratable acidity (TTA) expressed as the percentage of citric acid $100 \cdot \mathrm{g}^{-1}$ was determined using $7 \mathrm{~g}$ of tomato juice dissolved in $100 \mathrm{ml}$ of distilled water by titration with $\mathrm{NaOH} 0.1 \mathrm{~N}$ and phenolphthalein, according to the methodology used by Fabro et al. (2006), which is also specified in NTC 4623 (ICONTEC 1999 a). The content of the TTA in the sample was determined based on Eq. 1:

$$
\mathrm{TTA}(\%)=(\mathrm{V} \mathrm{NaOH} \times \mathrm{N} \mathrm{NaOH} \times 0.064 \times 100) / \mathrm{V} \text { sample }
$$

Vitamin C was achieved with $15 \mathrm{~g}$ of tomato juice dissolved in $15 \mathrm{ml}$ of distilled water for titration with iodine solution in $24.1 \mathrm{mmol} \cdot \mathrm{L}^{-1}$ and starch at $1 \%$ and $\mathrm{HCl}$ at $15 \%$ as previously used by Aguirre and Cabrera (2012) and specified in NTC 440 (ICONTEC 1996).

The $\mathrm{pH}$ of the fruit was analyzed with pHmeter type HI-9126 (Hanna Instruments, Romania, Europe). Soluble solids (SS) content expressed as ${ }^{\circ} \mathrm{Brix},\left(\right.$ at $20^{\circ} \mathrm{C}$ ) was analyzed in ABBE refractometer type WYA-2S (Optic Ivymen System, China) according to NTC 4624 (ICONTEC 1999 b). Finally, fruit color was analyzed measuring in the middle point between the base and the calyx area of each tomato with colorimeter type WR-10 (FRU, China), analyzing $\mathrm{L}^{\star}, \mathrm{a}^{*}$ and $\mathrm{b}^{*}$ coordinates.

\section{Extraction and quantification of antioxidants}

$\beta$-carotene and lycopene were determined according to the method previously used by Aguirre and Cabrera (2012). Extraction was performed with $0.6 \mathrm{~g}$ of tomato juice. Five milliliters of acetone:hexane solution (4:6) were added and centrifuged at $5000 \mathrm{rpm}$ for $5 \mathrm{~min}$ at $4{ }^{\circ} \mathrm{C}$. The supernatant was analyzed and measured in a visible light spectrophotometer at four different wavelengths: 453, 505, 645 and $663 \mathrm{~nm}$. Lycopene and $\beta$-carotene concentrations were obtained using Eqs. 1 and 2, respectively (Nagata and Yamashita 1992):

$$
\begin{aligned}
& \text { Lycopene }\left(\mu \mathrm{g} \cdot \mathrm{ml}^{-1}\right)=0.0458^{\star} \mathrm{A} 663+0.204^{\star} \mathrm{A} 645+0.372^{\star} \mathrm{A} 505-0.0806^{\star} \mathrm{A} 453 \\
& \beta \text {-carotene }\left(\mu \mathrm{g} \cdot \mathrm{ml}^{-1}\right)=0.216^{\star} \mathrm{A} 663-1.220{ }^{*} \mathrm{~A} 645-0.304{ }^{\star} \mathrm{A} 505+0.452^{\star} \mathrm{A} 453
\end{aligned}
$$




\section{Statistical analysis}

Data collected were processed in the SPSS program v.24 (IBM Corp, 2016). Assumptions of normality and homoscedasticity were verified (Shapiro-Wilk test and Levene's test). To analyze the differences between accessions, an ANOVA or a KruskallWallis test was applied (depending on Shapiro-Wilk and Levene's tests). The analysis was simultaneously complemented with the Duncan's or Dunn's tests, respectively, with differences at $\mathrm{p}<0.05$. Multivariate analysis (PCA) and heat map containing the effect of all variables were performed in the 11 accessions.

A multicriteria decision making (MCDM) was performed with highlighted accessions in at least one of the physicochemical parameters of interest. For this analysis, the data were first standardized due to the diversity of the measurement scales.

After that, an assignation mechanism of appropriate weightings was performed for decision criteria. Due to the relatively unexplored nature of this methodological application within this field of science, the attainment of a combined weighting was used between a subjective and objective strategies.

On the first strategy, four experts were asked to prioritize the variables $\left(\mathrm{pH}\right.$, lycopene, $\beta$-carotene, acidity, ${ }^{\circ} \mathrm{Brix}$, and vitamin $\mathrm{C}$ ), according to their relevance for the selection of the most promissory accession. Weights obtained were averaged among the diverse assessments generated by experts. The entropy criterion methodology was used for the attainment of objective weightings, which is based on the amount of intrinsic information provided by the data themselves, by assessing their variability and weighting their occurrence probabilities (Amorocho-Daza et. al. 2019). Under this perspective the preferential weightings resulting from the combination of both procedures were averaged. Preference ranking organization method for enrichment evaluation (PROMETHEE) was used as a MCDM method, which makes use of the over-ranking scores for a set of alternatives to be prioritized and then selects among multiple peer-to-peer criteria that oppose each other (Polat 2015). This method finally shows an over-ranking netflow $(\phi)$ where accession with the highest score is considered outranking in this study, according to physicochemical parameters and antioxidants contents.

\section{RESULTS AND DISCUSSION}

Physicochemical parameters and concentration of antioxidants from the 11 accessions of wild cherry-type tomatoes confirmed high variability, which can be mostly given by genetic variability or specific crop conditions as the irrigation deficit, available nitrogen concentration, among others (Coyago-Cruz et al. 2018).

\section{Physicochemical parameters}

Cherry tomato accumulates glucose and fructose, phenols, minerals and organic acids that make part of the SS and contribute to fruit flavor. The content of SS increases with some crop environmental conditions and ripening stages (Agius and Tucher 2018). Studies in this type of tomato indicate that the content of SS increases with the irrigation deficit on the crops which intensifies its flavor and therefore, the quality of the fruit (Coyago-Cruz et al. 2018). According to Ayala-Zavala et al. (2008), tomato fruit counts with $4.35 \pm 0.07^{\circ} \mathrm{Brix}$. Besides, Carbonell-Barrachina et al. (2006) found values of soluble solids (SS) in traditional varieties of tomato with ranges approximately between 3 to $5{ }^{\circ} \mathrm{Brix}$. In this study, ANOVA for SS showed significant differences ranging from $3.87^{\circ} \mathrm{Brix}$ in IAC412 to $8.10^{\circ} \mathrm{Brix}$ in IAC1621 (Fig. 1a). SS values was highest in IAC1621, IAC401, LA2076, IAC426, IAC391, and LA2692 (8.10 to 6.80), and lowest in IAC1624, IAC426R, LA1480, LA1705, and IAC412 (5.70 to 3.87). High values of SS are a desirable feature mainly on the cherry-type tomato (CarbonellBarrachina et al. 2006).

Optimum pH for microorganism's growth is close to neutrality at around 7.8 (Ramos and Zúñiga 2008). For this reason, low $\mathrm{pH}$ values in fruits can be used as an intrinsic defense mechanism against the colonization of microorganisms. However, there are microorganisms that grow in lower $\mathrm{pH}$ conditions than the optimum. The $\mathrm{pH}$ of each accession was quite variable as 
(a)

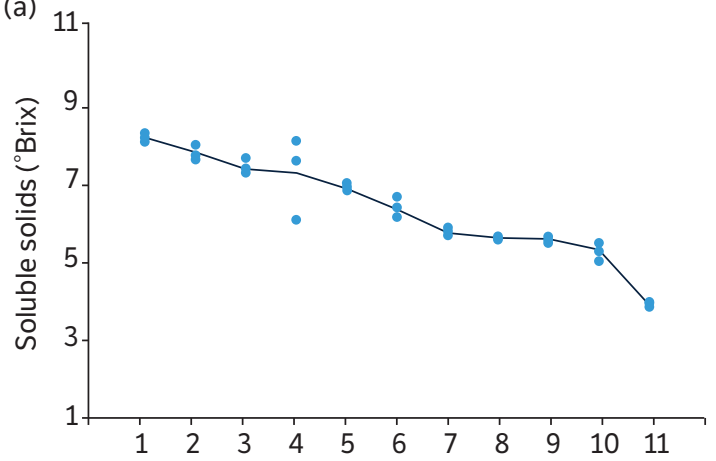

(c)



(b)

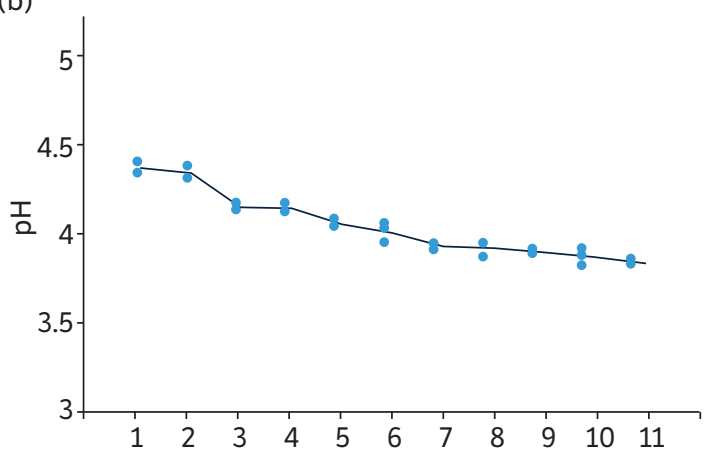

(d)

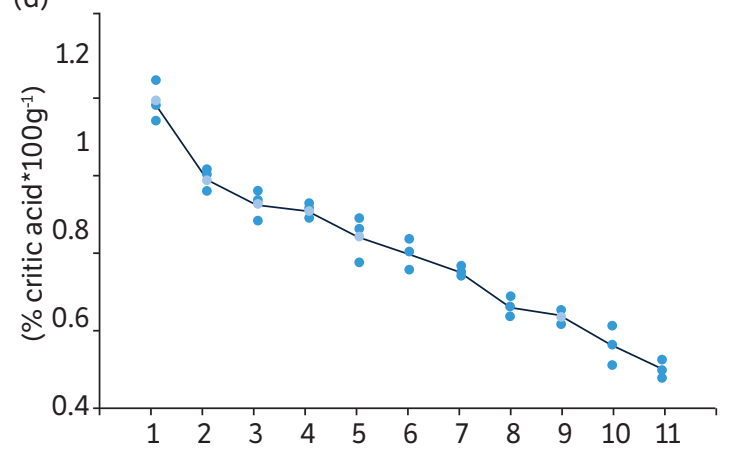

Accession code: 1: IAC1621, 2: IAC401, 3: IAC426, 4: IAC391, 5: LA2692, 6: LA2076, 7: IAC1624, 8: IAC426R, 9: LA1480, 10: LA1705, 11: IAC412 Figure 1. Physicochemical parameters evaluated in wild cherry tomatoes.

it was grouped in three sets which represent different ranges (Fig. 1b). The first group constituted by LA1480, IAC1621, IAC1624, LA1705, LA2076, LA2692 and IAC412 with the low $\mathrm{pH}$ values, the lowest value was 3.85 in IAC412. The second group was composed by IAC426, and IAC426R. A pH of 4.38 and 4.35 was found for IAC391 and IAC401 respectively in the third group. The authors of this work conclude that $\mathrm{pH}$ in the cherry-type tomato is mildly acidic. This value is related to the total acidity concentration that a tomato can exhibit.

Vitamin C is one of the water-soluble antioxidants in tomato which significantly reduces the adverse effects of the oxygen and the reactive nitrogen (Bhandari and Lee 2016), contributing to the prevention of diseases as a lipophilic antioxidant (García-Valverde et al. 2013). For vitamin C and TTA, three groups among the accessions were differentiated. The first group corresponds to lowest concentration of vitamin C (LA1480, LA1705, IAC426, and IAC426R), which is also the group with the lowest concentration of titratable acidity of cherry tomato analyzed, containing $10 \mathrm{mg} \cdot \mathrm{kg}^{-1}$ or less (Fig. 1c). The second group is related to IAC391, IAC1621, IAC1624, IAC412, and LA2692. The third group was constituted by IAC401, which presented levels of ascorbic acid of $50 \mathrm{mg} \cdot \mathrm{kg}^{-1}$.

The acidity values are associated with vitamin C content and other organic acids. IAC401 presented the highest percentage with $1.09 \%$ of citric acid $100 \mathrm{~g}^{-1}$ of LA1705 presented the lowest percentage with an acidity of $0.49 \%$ of citric acid $\cdot 100 \mathrm{~g}^{-1}$ (Fig. 1d). Aguirre and Cabrera (2012) found values of ascorbic acid for cherry tomatoes from 33 to $73 \mathrm{mg} \cdot 100 \mathrm{~g}^{-1}$ for IAC426, LA1705, and LA1480. (Nour et al. 2013) found values higher than $91.9 \mathrm{mg} \cdot \mathrm{kg}^{-1}$ in tomato. For this reason, IAC401 among the assessed fruit can be used as a natural source of vitamin $\mathrm{C}$. The suggested percentage of ascorbic acid in a daily intake for an adult is 75-90 mg per day (FAO and WHO 2001). In this sense, by consuming some fruits of IAC401, a person obtains approximately $100 \mathrm{mg} \cdot \mathrm{kg}^{-1}$ of vitamin C.

Color parameters indicate the ripening degree of a fruit (Fernández-Ruiz et al. 2010). Regarding the color of wild cherry tomato accessions, the distribution of $\mathrm{L}^{*}$ value (Fig. 2a) that corresponds to the brightness of the color was higher in LA1705 (54.433) and lower in IAC1621 (30.24). The $\mathrm{a}^{*}$ value (Fig. 2b), that indicates redness, was highest in IAC1624 fruits and lowest in IAC412 and LA1705. The value $b^{*}$ (Fig. 2c) indicates yellowness and was higher in LA1705 (36.18) 

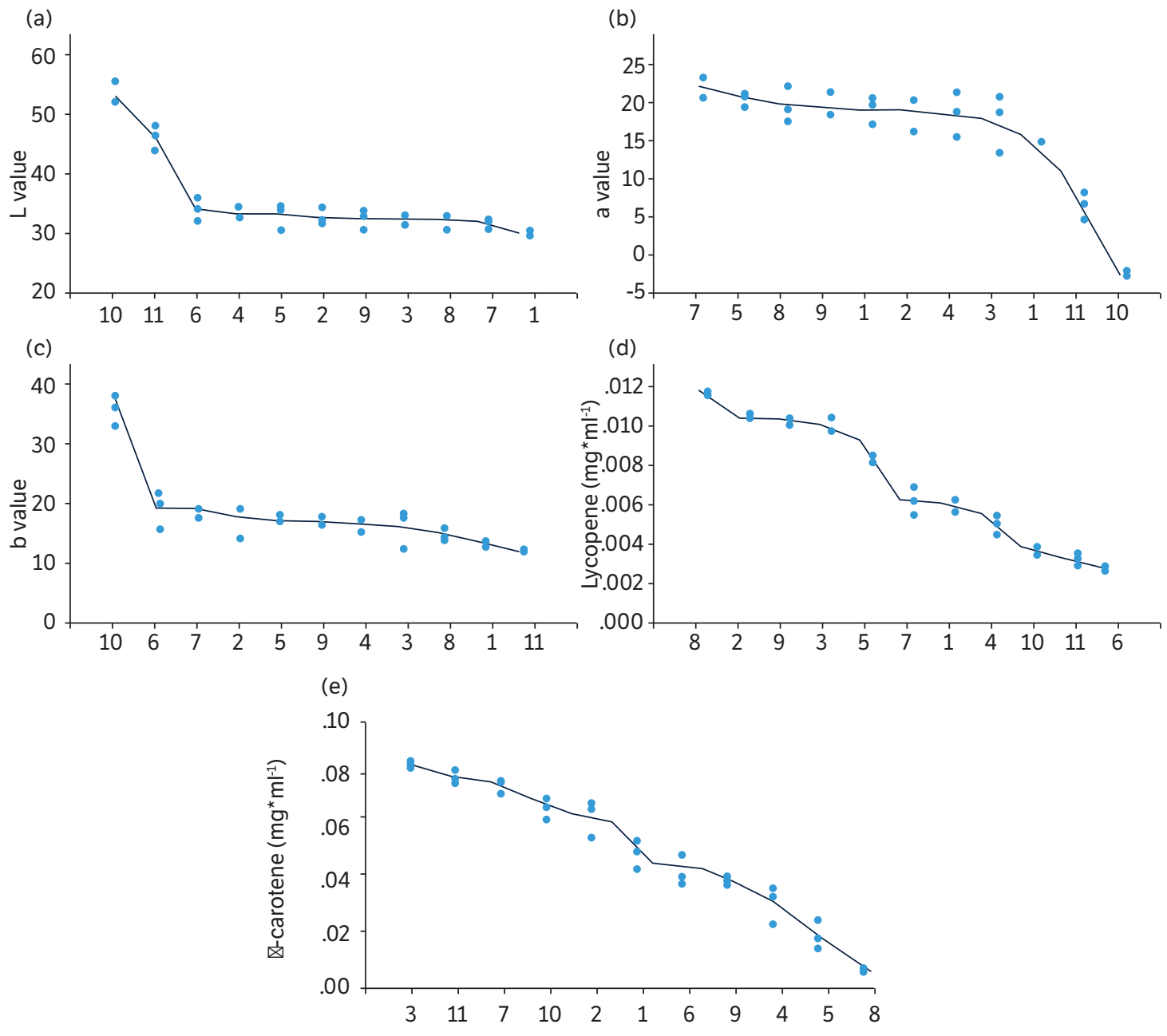

Accession code: 1: IAC1621, 2: IAC401, 3: IAC426, 4: IAC391, 5: LA2692, 6: LA2076, 7: IAC1624, 8: IAC426R, 9: LA1480, 10: LA1705, 11: IAC412

Figure 2. Physicochemical Parameters evaluated in wild cherry tomatoes.

and lower in IAC412 (12.74). These values could be associated with concentrations of lycopene, as the conditions of the crop take part of the proper ripeness of the fruit of the conventional tomato, specially the temperature which also has an impact on its development. This antioxidant increases on the last stage of ripening and provides the characteristic red color of tomato (Nour et al. 2013).

\section{Antioxidants concentration}

$\beta$-carotene, $\alpha$-carotene, and lycopene are the most active and important carotenoids for humans (Teixeira et al. 2009). $\beta$-carotene is the second most known antioxidant in the cherry-type tomato after lycopene. It has been related along with vitamin $C$ in the prevention of cardiovascular diseases (Cortés-Olmos et al. 2014). $\beta$-carotene is the main precursor of vitamin A (Giudice et al. 2017), which is important for the human vision. $\beta$-carotene concentrations in this study were higher in IAC426R, IAC412, followed by IAC1624, LA1705, IAC401, LA1480, IAC1621 and, LA2076, and lower in IAC391, LA2692, and IAC426. The accession IAC426R presented the highest value of $\beta$-carotene with $0.00825 \mu \mathrm{g} \cdot \mathrm{mL}^{-1}$ and the lowest value for IAC426 with $0.00069 \mu \mathrm{g} \cdot \mathrm{mL}^{-1}$ (Fig. 2e). Studies performed by García-Valverde et al. (2013) related values of $\beta$-carotene ranging from $0.76 \mathrm{mg} \cdot \mathrm{kg}^{-1}$ on the green 'Ronaldo' tomato to $5.44 \mathrm{mg} \cdot \mathrm{kg}^{-1}$ fresh weight (pink pear tomato). 
In addition, Aguirre and Cabrera (2012) reported values from 0 to $0.96 \mu \mathrm{g} \cdot \mathrm{mL}^{-1}$ and Nour et al. (2013) found values of 0.008 to $0.027 \mu \mathrm{g} \cdot \mathrm{mL}^{-1}$ for tomato. In a recent study, Coyago-Cruz et al. (2018) reported this antioxidant ranging from 1.8 to $37.9 \mathrm{mg} \cdot 100 \mathrm{~g}^{-1}$ fresh weight.

According to Tukey's test, IAC426, IAC401, LA1480, IAC426R, LA2692, IAC1621, and IAC1624 presented the highest concentrations of lycopene (Fig. 2d), while IAC391, LA1705, IAC412, and LA2076 presented the lowest concentrations. IAC426 contained $0.01166 \mu \mathrm{g} \cdot \mathrm{mL}^{-1}$ of lycopene, the pink fruit IAC412 and LA2076 showed the lowest values of this antioxidant. Therefore, and according to the results, a relation with the content of antioxidants, such as lycopene and red pigment in tomato, could be established. Similar relations were estimated with $\mathrm{L}^{*}, \mathrm{a}^{*}$ and $\mathrm{b}^{*}$ values, which indicate ripening and, thus, relate the lycopene content (Fernández-Ruiz et al. 2010). Concentrations of lycopene depends on the tomato genotype, ripening stage and its interaction with the environment. Coyago-Cruz et al. (2018) found lycopene levels between 3.1 and $259.5 \mathrm{mg} \cdot 100 \mathrm{~g}^{-1}$ of dry weight in samples of diverse tomatoes cultivars, being higher at maximum ripening stage than in other stages (Bhandari and Lee 2016). The intensity of sunlight favors the biosynthesis of carotenoids (especially lycopene) (Aguirre and Cabrera 2012), as well as the temperature which the plants are established (Dumas et al. 2002).

The difference in lycopene concentrations in this study is explained by the genotype. Nevertheless, the general average values of antioxidants are significantly lower than that obtained with same accessions analyzed under field conditions by Aguirre and Cabrera (2012). The intensity of light is probably the factor that generated this difference.

In this sense, the values obtained can also differ depending on the type of extraction and quantification. The method used for this study through a spectrophotometry is considered easy, economical and fast (D'Souza et al. 1992; Aguirre and Cabrera 2012; Kavitha et al. 2014; Zouari et al. 2014; Porto et al. 2016; Del Giudice et al. 2017), and is generally useful when associated with other parameters for a group analysis. Nevertheless, these measurements can be done through diverse techniques, many of them reported for tomato or related subproducts.

For PCA (Fig. 3a), the three first components presented a total of $79.2 \%$ of the data total variability. The graphic representation of the two first components summarizes to a large extent the fundamental differences existing among the accessions.

In synthesis, the average promissory fruits for growing are associated in the core of PCA (red circle). The accessions which are not selected as promissory due do their physicochemical characteristics are inside the black circle; and IAC401 is inside the green circle, which presented the highest level of acidity and vitamin C.

The heat map (Fig. 3b) confirm above mentioned. Accessions LA1705 and LA2692 had less intense colors, making them uninteresting in this analysis. It would be interesting to confront the physicochemical values of accessions, such as IAC401, with sensorial attributes, since they can be affected with unwanted bitter tastes (Tandon et al. 2003).

To perform the multicriteria decision analysis (Table 2), several aspects were considered. The first aspect was to exclude accessions with low values for the parameters of interest (IAC391, LA1705, LA2692). Once the study was performed, IAC401 with a $\varnothing$ (a) of 0.50 can be considered the most promissory to be taken as a functional food crop. In this order, the positive values of $\varnothing$ (a) were also obtained for IAC426 and IAC1624.

\section{CONCLUSION}

Physicochemical parameters of the cherry-type tomatoes reveal the differences regarding its genotype, since the accessions were cultivated under the same conditions and collected at ripening for subsequent analysis. Additionally, the Brazilian red accession IAC426 and IAC426R, belonging to the same accession, differ by the oval-round shape of the fruit respectively at a qualitative level. At a quantitative level, they showed a similar $\mathrm{pH}$ of 4.1 and differences on the total acidity, antioxidants concentration, and vitamin C content, in which IAC426R has the highest value.

Tomatoes present changing sizes and shapes, however, in terms of color, the accessions that were not red (LA1705 and IAC412) presented significant differences in physicochemical parameters, especially in color and in antioxidant contents. 
(a)

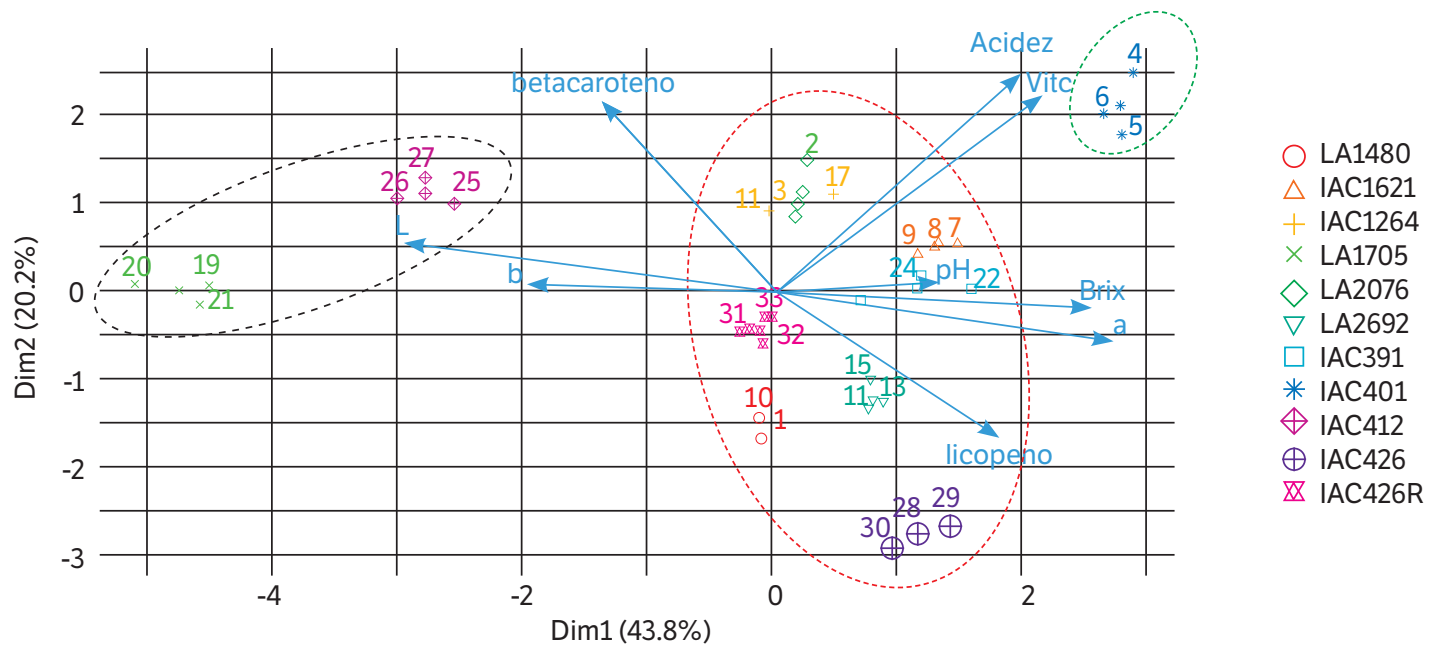

(b)

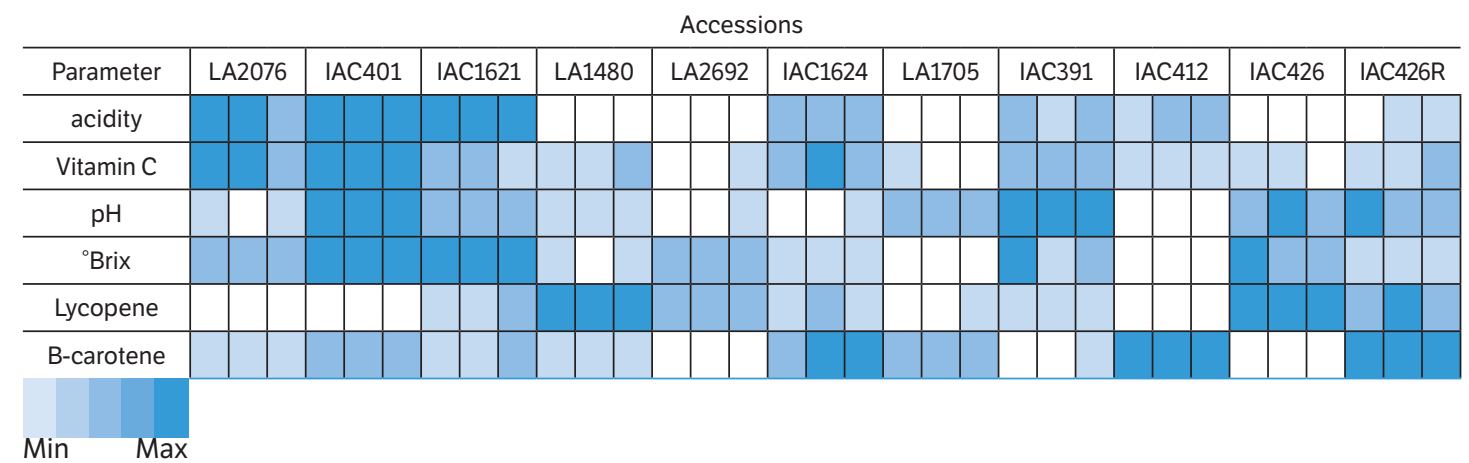

Figure 3. Comparison between accessions according physicochemical parameters A. PCA of the interaction of the studied physicochemical variables and wild cherry tomato accessions. B. Heat map based on the concentrations of the physicochemical variables evaluated in 11 accessions of wild cherry-type tomatoes.

Table 2. Multicriteria decision analysis by using the PROMETHEE method for the selection of the wild cherry-type tomatoes accession by means of physicochemical parameters and the antioxidants content.

\begin{tabular}{|c|c|c|c|c|c|c|c|c|}
\hline Accession & LA1480 & IAC1621 & IAC1624 & LA2076 & IAC401 & IAC412 & IAC426 & IAC426R \\
\hline$\phi(a)$ & 0.2787 & 0.4321 & 0.5244 & 0.3113 & 0.7164 & 0.3369 & 0.3918 & 0.5273 \\
\hline$\phi-(a)$ & 0.5137 & 0.4690 & 0.3403 & 0.5625 & 0.2154 & 0.5283 & 0.5587 & 0.3310 \\
\hline \multirow[t]{2}{*}{$\phi+(a)$} & -0.2349 & -0.0369 & 0.1841 & -0.2512 & 0.5010 & -0.1914 & -0.1669 & 0.1963 \\
\hline & \multicolumn{8}{|c|}{ Preference Order } \\
\hline \multirow[t]{2}{*}{ Accession } & $1^{\circ}$ & $2^{\circ}$ & $3^{\circ}$ & $4^{\circ}$ & $5^{\circ}$ & $6^{\circ}$ & $7^{\circ}$ & $8^{\circ}$ \\
\hline & IAC401 & IAC426R & IAC1624 & IAC1621 & IAC426 & IAC412 & LA1480 & LA2076 \\
\hline
\end{tabular}

The International Life Science Institute defines as a functional the food whose physiologically active components represent a benefit for human health beyond their basic benefits (Navarro-González and Periago 2016). Solanum lycopersicum L. var. cerasiforme tomato can be considered healthy and a functional food, due to its components.

In cooperation with all performed analysis and based on the multicriteria decision making, IAC401 and IAC1624 can be considered promissory for commercial seeding and for establishing as a functional food, due to the fact they present a low $\mathrm{pH}$ level, considerable levels of vitamin C, SS average values, and a higher lycopene and $\beta$-carotene content among the analyzed accessions. 


\section{ACKNOWLEDGMENTS}

The authors want to acknowledge the Department of Science and Technology of Colombia (COLCIENCIAS), also for L. M. Londoño's scholarship obtained through the National Ph.D. Call 727 of 2015, and to Catholic University of Manizales for its support during the project.

\section{AUTHOR'S CONTRIBUTION}

Conceptualization, Corpas E., Taborda G. and Londoño L. M.; Methodology, Tapasco O. and Baena A.; Investigation, Gonzalez J., Baena A. M., Tapasco O. and Londoño L. M.; Writing - Original Draft, Gonzalez J. and Londoño L. M.; Writing - Review and Editing, Gonzalez J., Londoño L. M. and Baena A. M.; Funding Acquisition, Corpas E. J. and Taborda G.; Resources, Corpas E. J. and Taborda G.; Supervision, Londoño L. M.

\section{REFERENCES}

[FAO] Food and Agriculture Organization of the United Nations; [WHO] World Health Organization. (2001). Human vitamin and mineral requirements. Human vitamin and Mineral Requirements, 249-269. [Accessed Mar. 31, 2020]. Available at: http://www.fao.org/3/a-y2809e.pdf [IBM] International Business Machines Corporation. (2016). SPSS Statistics para Windows. New York: Armonk.

[ICONTEC] Instituto Colombiano de Normas Técnicas y Certificación. (1996). NTC 440. Productos alimenticios. Métodos de Ensayo. Bogotá: ICONTEC. [Accessed Mar. 31, 2020]. Available at: https://portal.icontec.org/consulta_publica/

[ICONTEC] Instituto Colombiano de Normas Técnicas y Certificación. (1999 a). NTC 4623. Productos de frutas y verduras. Determinación de la acidez titulable. Bogotá: ICONTEC. [Accessed Mar. 31, 2020]. Available at: https://portal.icontec.org/consulta_publica/

[ICONTEC] Instituto Colombiano de Normas Técnicas y Certificación. (1999b). NTC 4624. Jugos de frutas y hortalizas. Determinación del contenido de sólidos solubles. Método refractométrico. (p.1-9). Bogotá: ICONTEC. [Accessed Mar. 31, 2020]. Available at: https:// portal.icontec.org/consulta_publica/

Agius, C., von Tucher, S., Poppenberger, B. and Rozhon, W. (2018). Quantification of sugars and organic acids in tomato fruits. MethodsX, 5, 537-550. https://doi.org/10.1016/j.mex.2018.05.014

Agudelo, A. G. A., Aguirre, N. C. and Orozco, F. J. (2011). Caracterización morfológica del tomate tipo cereza (Solanum lycopersicum LINNAEUS). Agronomía, 19, 44-53.

Aguirre, N. C. and Cabrera, F. A. V. (2012). Evaluating the fruit production and quality of cherry tomato (Solanum lycopersicum var. cerasiforme). Revista Facultad Nacional de Agronomía Medellín, 65, 6593-6604.

Aldrich, H. T., Salandanan, K., Kendall, P., Bunning, M., Stonaker, F., Külen, O. and Stushnoff, C. (2010). Cultivar choice provides options for local production of organic and conventionally produced tomatoes with higher quality and antioxidant content. Journal of the Science of Food and Agriculture, 90, 2548-2555. https://doi.org/10.1002/jsfa.4116

Amorocho-Daza, H., Cabrales, S., Santos, R. R., Saldarriaga, J. (2019). A New Multi-Criteria Decision Analysis Methodology for the Selection of New Water Supply Infrastructure. Water, 11, 1-23. https://doi.org/10.3390/w11040805

Ayala-Zavala, J. F., Oms-Oliu, G., Odriozola-Serrano, I., González-Aguilar, G. A., Álvarez-Parrilla, E. and Martín-Belloso, O. (2008). Biopreservation of fresh-cut tomatoes using natural antimicrobials. European Food Research and Technology, 226, 1047-1055. https://doi. org/10.1007/s00217-007-0630-z 
Bhandari, S. R. and Lee, J. G. (2016). Ripening-dependent changes in antioxidants, color attributes and antioxidant activity of seven tomato (Solanum lycopersicum L.) cultivars. Journal of Analytical Methods in Chemistry, 2016, 5498618, 1-13. https://doi.org/10.1155/2016/5498618

Carbonell-Barrachina, A. A., Agustí, A. and Ruiz, J. J. (2006). Analysis of flavor volatile compounds by dynamic headspace in traditional and hybrid cultivars of Spanish tomatoes. European Food Research and Technology, 222, 536-542. https://doi.org/10.1007/s00217-005-0131-x

Corbet, C., Pinto, A., Martherus, R., Jesus, J. P. S., Polet, F. and Feron, O. (2016). Acidosis drives the reprogramming of fatty acid metabolism in cancer cells through changes in mitochondrial and histone acetylation. Cell Metabolism, 24, 311-323. https://doi.org/10.1016/j. cmet.2016.07.003

Cortés-Olmos, C., Leiva-Brondo, M., Roselló, J., Raigónc, M. D. and Cebolla-Cornejo, J. (2014). The role of traditional varieties of tomato as sources of functional compounds. Journal of the Science of Food and Agriculture, 94, 2888-2904. https://doi.org/10.1002/jsfa.6629

Coyago-Cruz, E., Corell, M., Moriana, A., Hernanz, D., Stinco, C. M. and Meléndez-Martínez, A. J. (2017). Effect of the fruit position on the cluster on fruit quality, carotenoids, phenolics and sugars in cherry tomatoes (Solanum lycopersicum L.). Food Research International, 100, 804-813. https://doi.org/10.1016/j.foodres.2017.08.002

Coyago-Cruz, E., Corell, M., Moriana, A., Hernanz, D., Benítez-González, A. M., Stinco, C. M. and Meléndez-Martínez, A. J. (2018). Antioxidants (carotenoids and phenolics) profile of cherry tomatoes as influenced by deficit irrigation, ripening and cluster. Food Chemistry, 240, 870-884. https://doi.org/10.1016/j.foodchem.2017.08.028

D’Souza, M. C., Singha, S. and Ingle, M. (1992). Lycopene concentration of tomato fruit can be estimated from chromaticity values. HortScience, 27, 465-466. https://doi.org/10.21273/HORTSCI.27.5.465

Del Giudice, R., Petruk, G., Raiola, A., Barone, A., Monti, D. M. and Rigano, M. M. (2017). Carotenoids in fresh and processed tomato (Solanum lycopersicum) fruits protect cells from oxidative stress injury. Journal of the Science of Food and Agriculture, 97, 1616-1623. https://doi.org/10.1002/jsfa.7910

Dumas, Y., Dadomo, M., Di Lucca, G. and Grolier, P. 2002. Review of the influence of major environmental and agronomic factors on the lycopene content of tomato fruit. Acta Horticulturae, 579, 595-601. https://doi.org/10.17660/ActaHortic.2002.579.105

Fabro, M. A., Milanesio, H. V., Robert, L. M., Speranza, J. L., Murphy, M., Rodríguez, G. and Castañeda, R. (2006). Determination of acidity in whole raw milk: comparison of results obtained by two different analytical methods. Journal of Dairy Science, 89, 859-861. https://doi. org/10.3168/jds.S0022-0302(06) 72149-X

Fernández-Ruiz, V., Torrecilla, J. S., Cámara, M., Mata, M. C. S. and Shoemaker, C. (2010). Radial basis network analysis of color parameters to estimate lycopene content on tomato fruits. Talanta, 83, 9-13. Elsevier, https://doi.org/10.1016/j.talanta.2010.08.020

García-Valverde, V., Navarro-González, I., García-Alonso, J. and Periago, M. J. (2013). Antioxidant bioactive compounds in selected industrial processing and fresh consumption tomato cultivars. Food and Bioprocess Technology, 6, 391-402. https://doi.org/10.1007/ s11947-011-0687-3

Kavitha, P., Shivashankara, K. S., Rao, V. K., Sadashiva, A. T., Ravishankar, K. V. and Sathish, G. J. (2014). Genotypic variability for antioxidant and quality parameters among tomato cultivars, hybrids, cherry tomatoes and wild species. Journal of the Science of Food and Agriculture, 94, 993-999. https://doi.org/10.1002/jsfa.6359

Lucini, L., Pellizzoni, M., Baffi, C. and Molinari, G. P. (2012). Rapid determination of lycopene and $\beta$-carotene in tomato by liquid chromatography/electrospray tandem mass spectrometry. Journal of the Science of Food and Agriculture, 92, 1297-1303. https://doi. $\operatorname{org} / 10.1002 / j s f a .4698$

Melfi, M. T., Nardiello, D., Cicco, N., Candido, V. and Centonze, D. (2018). Simultaneous determination of water- and fat-soluble vitamins, lycopene and beta-carotene in tomato samples and pharmaceutical formulations: Double injection single run by reverse-phase liquid chromatography with UV detection. Journal of Food Composition and Analysis, 70, 9-17. https://doi.org/10.1016/j.jfca.2018.04.002 
Nagata, M. and Yamashita, I. (1992). Simple method for simultaneous determination of chlorophyll and carotenoids in tomato fruit. Japanese Society for Food Science and Technology, 39, 925-928. https://doi.org/10.3136/nskkk1962.39.925

Navarro-González, I. and Periago, M. J. (2016). El tomate, ¿alimento saludable y/o funcional? Revista Española de Nutrición Humana y Dietética, 20, 323-335. https://doi.org/10.14306/renhyd.20.4.208

Nour, V., Trandafir, I. and Ionica, M. E. (2013). Antioxidant compounds, mineral content and antioxidant activity of several tomato cultivars grown in Southwestern Romania. Notulae Botanicae Horti Agrobotanici Cluj-Napoca, 41, 136-142. https://doi.org/10.15835/nbha4119026

Polat, G. (2015). Subcontractor selection using the integration of the AHP and PROMETHEE methods. Journal of Civil Engineering and Management, 22, 1042-1054. https://doi.org/10.3846/13923730.2014.948910

Poojary, M. M. and Passamonti, P. (2015). Extraction of lycopene from tomato processing waste: Kinetics and modelling. Food Chemistry, 173, 943-950. https://doi.org/10.1016/j.foodchem.2014.10.127

Porto, J. S., Rebouças, T. N. H., Moraes, M. O. B., Bomfim, M. P., Lemos, O. L. and Luz, J. M. Q. (2016). Quality and antioxidant activity of tomato cultivated under different sources and doses of nitrogen. Revista Caatinga, 29, 780-788. https://doi.org/10.1590/1983-21252016v29n401rc

Rabiee, S., Tavakol, S., Barati, M. and Joghataei, M. T. (2018). Autophagic, apoptotic and necrotic cancer cell fates triggered by acidic pH microenvironment. Journal of Cellular Physiology, 234, 12061-12069. https://doi.org/10.1002/jcp.27876

Ramos, E. and Zúñiga, D. (2008). Efecto de la humedad, temperatura y pH del suelo en la actividad microbiana a nivel de laboratorio. Ecología Aplicada, 7, 1-2, 1726-2216. https://doi.org/10.21704/rea.v7i1-2.367

Schweiggert, R. M., Ziegler, J. U., Metwali, E. M. R., Mohamed, F. H., Almaghrabi, O, A., Kadasa, N. M. and Carle, R. (2017). Carotenoids in mature green and ripe red fruits of tomato (Solanum lycopersicum L.) grown under different levels of irrigation. Archives of Biological Sciences, 69, 305-314. http://doi.org/10.2298/ABS160308102S

Servili, M., Selvaggini, R., Begliomini, A. L. and Montedoro, G.F. (1998). Effect of thermal treatment in the headspace volatile compounds of tomato juice. Developments in Food Science, 40, 315-330. https://doi.org/10.1016/S0167-4501(98)80056-3

Tandon, K. S., Baldwin, E. A., Scott, J. W. and Shewfelt, R. L. (2003). Linking sensory descriptors to volatile and nonvolatile components of fresh tomato flavor. Journal of Food Science, 68, 2366-2371. https://doi.org/10.1111/j.1365-2621.2003.tb05774.x

Teixeira, C. I. A., Da, P., Euge, B. M., Maria, S. and Haracemiv, C. (2009). Extraction of lycopene from tomato sauce with mushrooms (Agaricus brasiliensis), determined by high-performance liquid chromatography. International Journal of Food Sciences Nutrition, 60 , Supp 1, 72-78. https://doi.org/10.1080/09637480802090445

Thies, F., Mills, L. M., Moir, S. and Masson, L. F. (2016). Cardiovascular benefits of lycopene: Fantasy or reality? Proceedings of the Nutrition Society, 76, 1-8. https://doi.org/10.1017/S0029665116000744

Tian X, Wang J, Hong, X. and Wang, C. (2016). Fast determination of lycopene content and soluble solid content of cherry tomatoes using metal oxide sensors based electronic nose. Acta Alimentaria, 45, 182-189. https://doi.org/10.1556/AAlim.2015.0006

Zanfini, A., Franchi, G. G., Massarelli, P., Corbini, G. and Dreassi, E. (2017). Phenolic compounds, carotenoids and antioxidant activity in five tomato (Lycopersicon esculentum mill.) cultivars. Italian Journal of Food Science, 29, 90-100. https://doi.org/10.14674/1120-1770/ijfs.v316

Zouari, I., Salvioli, A., Chialva, M., Novero, M., Miozzi, L., Tenore, G. C., Bagnaresi, P. and Bonfante, P. (2014). From root to fruit: RNASeq analysis shows that arbuscular mycorrhizal symbiosis may affect tomato fruit metabolism. BMC Genomics, 15, 2-19. https://doi. org/10.1186/1471-2164-15-F 